soil can be appreciably altered through the control of the amount and, more important still, the kind of humus produced.

In the subsequent discussion, Sir Roy Robinson explained that the exigencies of the moment had largely determined the selection of conifers for planting, and that it was likely that the next generation of the forest would, in certain parts of Great Britain, at least differ markedly in composition particularly by the use of more hardwoods. This is welcome news; and more followed. For
Sir Roy announced on behalf of the Forestry Commission the initiation of a programme of closer co-operation between the forester and the scientific worker, particularly the ecologist, and offered to set aside quite considerable areas in selected forests for purposes of scientific study, primarily for a periodic record of the changes in the vegetation. But many scientific interests are involved, and one may look for results fruitful to science generally as well as to the forester, from this opportunity to study a forest in the making.

\title{
Limestones as Eruptive Rocks
}

$\mathrm{T}$ HE carbonate-rocks, especially limestones and dolomites, are so well known as sedimentary or metamorphosed sedimentary rocks that there may be some surprise that petrologists of Section C (Geology) of the British Association spent the greater part of a day during the recent Cambridge meeting in discussing the origin of carbonate-rocks associated with alkali-rich intrusions.

The occurrence of limestones in close association with alkali-rich rocks, such as nepheline-syenites, phonolites and related types, has been observed with great frequency and it has commonly been assumed that the limestones, where not clearly belonging to a sedimentary formation, were relics of sedimentary limestones assimilated in depth by the igneous magmas.

According to a widely accepted theory proposed by R. A. Daly in 1910, such assimilation of limestone by sub-alkaline magmas is the cause of the formation of the alkali-rich igneous rocks.

However, so early as 1892, some limestones occurring in the form of dykes and cutting the volcanic rocks of the Kaiserstuhl in Baden, were described by $\mathbf{A}$. Knop, and three years later A. G. Hogböm described limestone dykes in a region of alkali-rich intrusives on the island of Alnö in Sweden. Hogböm also recorded calcite as a primary mineral in some rocks at Alnö, and there were other descriptions of primary calcite in alkalieruptive rocks from Canada and India. In view of the readiness with which calcite dissociates on heating, geologists were reluctant to accept it as a primary mineral or to believe in limestone intrusions, but during the last few years much fresh evidence of apparently intrusive carbonaterocks has been obtained.

The most convincing new evidence comes again from Alnö, where the rocks are now far better exposed than they were at the time of Hogböm's visits forty-three years ago. They have been studied thoroughly by Dr. Harry von Eckermann, of Stockholm, who opened the discussion at Cambridge. A large area of alkali-intrusivesnepheline-syenites and ijolites-cuts the Precambrian gneisses and is probably late-Jotnian in age. Around the contact with the gneiss (which is altered) crystalline limestones appear, and outside the neck of intrusive rocks there are calcitic and dolomitic dykes which are shown to be conesheets dipping towards two deep central foci. From the inclination of the cone-sheets the focus of the calcite dykes can be shown to be at 1-2 km. below the present surface, and that for the dolomitic sheets at 6-7 km. The geology of the country near Alnö is well known, and von Eckermann regards it as certain that for hundreds of miles around and to great depths there is no trace of sedimentary limestone in the Archæan rocks of earlier age than the alkali-intrusives. All the evidence points to a magmatic origin for these limestones at Alnö.

Magmatic origin is also claimed by Dr. F. Dixey for the crystalline limestone associated with breccias filling remarkable vents of post-Karroo age in Southern Nyasaland. At one of the largest of these vents, Chilwa Island, limestone and orthoclase-breccias occupy a roughly circular area $1 \frac{1}{2}$ miles across and form steep cliffs rising $1,400 \mathrm{ft}$. above the level of Chilwa Lake. Nine larger and seven smaller vents are known, and at most of them the limestones are cut by small bodies or dykes of alkali-rich rocks, nepheline-syenite, ijolite, phonolite, or nephelinite. The rocks surrounding the vents are altered and there are many resemblances with the rocks of Alnö. As for the source of the limestone, Dr. Dixey finds that the small lenticles of limestone known to occur in the Basement Complex of the district are altogether too small and infrequent to have supplied the limestone for the great masses of the Chilwa vents, and the conclusion that they are in some way magmatic seems unaroidable. 
Mr. S. I. Tomkeieff had visited Fen in Norway, where the rocks, closely comparable with those at Alnö, were described in a classic paper by W. C. Brögger in 1921. He has no doubt about the magmatic origin of the carbonate rocks in that district.

Prof. S. J. Shand claimed that the limestones at Alnö and Fen, and at eight other localities which he listed, had been or ultimately would be proved to be derived from sedimentary or metamorphosed sedimentary limestones. He described two areas of alkali-rich rocks-Haliburton, Ontario, and Sekukuniland, Transvaal - where he regards it as demonstrable that carbonate-rocks associated with nepheline-syenite have been derived by the incorporation of sedimentary or metamorphic limestones by igneous magma.

Prof. C. E. Tilley admitted that the limestonesyntexis theory is applicable in certain places to a limited extent and he believes that the limestone 'intrusions' in the Haliburton and Bancroft areas present certain peculiarities differentiating them from the other occurrences, but he claimed magmatic origin for every other example of limestone associated with alkali-rich rocks in Prof. Shand's list. He mentioned especially Magnet Cove, Arkansas, and Palabora, Transvaal, and he added two new examples: Iron Hill, Colorado, and Kabossero at the head of the White Sea.

The claim for magmatic origin of some of these limestones seems to rest on good field evidence, but it needs to be supported by a credible explanation of how magmatic limestones can be formed and why they are associated with alkali-rich intrusions. To this task Dr. von Eckermann devoted the last half of his address. He outlined the possible processes which might have effected the formation at the base of the Jotnian sheetintrusions of a nepheline-syenite magma rich in potash, carbon dioxide, fluorine and chlorine, and he traced the possible history of such a magma as it stoped its way upwards to a point at which the concentrated volatiles shattered the roof and more or less pure carbonates filled the conical fractures in the surrounding rock. Mr. Tomkeieff also was able to suggest a possible petrogenetic scheme for the rocks of Fen. He regards carbon dioxide as probably originally present in many rock magmas but lost by most during consolidation. Where it is retained, it must have a profound effect on the course of differentiation. While Dr. Eckermann made no claim that the explanation he had put forward applied outside Fennoscandia, Mr. Campbell Smith, referring to the rocks of the Chilwa Series of Southern Nyasaland, said that there are so many resemblances between them and the rocks at Alnö and Fen that processes which were active in Fennoscandia in the Archæan must have been operative at the Chilwa vents in postKarroo times. He said that in Nyasaland the problem is to explain the close connexion between the formation of pure orthoclase-rocks (remarkably rich in potash), their brecciation, the alteration of the country rocks, the supply of material for and the emplacement of the crystalline limestone, and the subsequent intrusion of alkali-rich rocks.

When the results of Dr. von Eckermann's work are published, it may be found that all these closely related events will find their places in the scheme of differentiation of which during the discussion he gave a brief description, but which lack of space here compels us to omit.

\section{Vibration in Engineering}

$\mathrm{F}^{\mathrm{o}}$ R the past few years, the council of the British Association, in co-operation with the various sections, has selected a number of scientific topics which are of direct interest to the general public, and by means of symposia or otherwise, to which workers in the particular fields concerned have contributed, general reviews of our present knowledge and the problems still to be solved have been arranged. Among the subjects chosen for the Cambridge meeting was vibration, a phenomenon which, in this mechanical age, is in daily evidence to every one of us, and the importance of which is very great. The engineer is concerned with its results upon the structure in which it occurs, which, in an aeroplane, for example, may be disastrous, and in any event will have a deterior. ating effect. The ordinary person, be he traveller in motor-car, train, ship or aeroplane, is more concerned with the discomfort (and even, maybe, injury to health), which accompanies continuous vibration. From whichever point of view it is regarded, therefore, vibration is a phenomenon which everyone desires to see eliminated or reduced to a minimum.

Any elastic structure, when disturbed from rest and released, will vibrate freely for some time in one of a number of possible modes, the particular one resulting depending upon the restraints imposed on the structure and upon the method of disturb. ance. The frequencies of these modes are called the 'natural' frequencies of the system. When a bridge or ship, for example, is subjected to a 